\title{
Uji Efektivitas Bio-Organic Fertilizer (Pupuk Organik Hayati) dalam Mensubstitusi Kebutuhan Pupuk Anorganik pada Tanaman Sweet Sorghum [Sorghum bicolor (L.) Moench]
}

\section{Effectivity Test of Bio-organic Fertilizer in order to Substitute Inorganic Fertilizer Necessity on Sweet Sorghum [Sorghum bicolor (L.) Moench]}

\author{
Ester LN Lumbantobing, Fahrizal Hazra, dan Iswandi Anas \\ Departemen Ilmu Tanah dan Sumberdaya Lahan, Fakultas Pertanian, Institut Pertanian Bogor \\ Jalan Meranti Kampus IPB Darmaga, Bogor 16680
}

\begin{abstract}
The aim of research was to examine the effectiveness of bio-organic fertilizer to substitute inorganic fertilizer necessity on sweet sorghum [Sorghum bicolor (L.) Moench] vegetative growth. This research was carried out in the University Farm green house Cikabayan and in the Leuwikopo Experiment Field, Institut Pertanian Bogor. The green house experiment used completely randomized design with six treatments, namely: 1. No fertilizer (control), 2. 100\%NPK, $3.50 \% N+$ DOP, 4. $50 \%$ NPK + Fertismart, 5. 50\%NPK + Ponti, dan 6. 50\%NPK + Biost. The field experiment used completely randomizes block design with seven treatments, namely: 1. No fertilizer (control), 2. 50\%NPK, 3. 100\%NPK, 4. 50\%N + DOP, 5. 50\%NPK + Fertismart, 6. $50 \%$ NPK + Ponti, and 7. 50\%NPK + Biost. Materials which was used were super sugar variety, NPK fertilizers, bio-organic fertilizer Fertismart, Ponti, Biost, and organic fertilizer Double Organic Phosphate (DOP).

The results of greeen house research showed that bio-organic fertilizer could increase crop height, number of leaves, wet weight upper crop, dry weight upper crop, wet weight root, and dry weight root of sweet sorghum than control and same with treatment of $100 \%$ NPK. Treatment of 50\%NPK + Biost could increase crop height (47.8\%) than control and same with treatment of $100 \%$ NPK. Treatment of 50\%NPK + Ponti increase dry weight root (59\%) than control and same with treatment of $100 \%$ NPK.

The results of field research showed that bio-organic fertilizer Fertismart could increase wet weight upper crop, crop height (42.8\%) and number of leaves (39.5\%) than control, and same with 100\%NPK. It means that bio-organic fertilizer could substitute about $50 \%$ inorganic necessity on sweet sorghum.
\end{abstract}

Keywords: bio-organic fertilizer, Azotobacter, Azospirillum, phosphate solubilizing microbes.

\section{PENDAHULUAN}

Bio-organic fertilizer (pupuk organik hayati) sejak dua dekade ini berkembang dengan pesat. Hal ini disebabkan karena kelangkaan pupuk anorganik yang menyebabkan harga pupuk semakin meningkat, kemasaman tanah yang meluas akibat penggunaan pupuk anorganik secara terusmenerus, dan meningkatnya permintaan terhadap produkproduk pertanian organik. Kendala-kendala pemupukan tersebut menyebabkan pupuk organik hayati berkembang dengan pesat bukan saja di luar negeri, tetapi juga di dalam negeri. Pupuk organik hayati ini adalah pupuk organik yang diperkaya dengan kandungan hara dan diinokulasikan dengan berbagai macam mikroba fungsional. Mikroba ini secara khusus diisolasi dan dikemas dalam bahan pembawa (carriers) yang mampu menjaga reaktivitasnya dalam periode yang memadai.

Mikroba tanah yang dikandung oleh pupuk organik hayati yang diuji pada penelitian ini adalah Azotobacter, Azospirillum dan mikroba pelarut fosfat. Mikroba-mikroba tersebut mampu melarutkan hara sehingga dapat memperbaiki pertumbuhan dan produksi tanaman.

Azotobacter adalah bakteri penambat $\mathrm{N}_{2}$ yang hidup bebas, bersifat Gram negatif, aerobik obligat, dan tumbuh baik pada media yang kekurangan N (Imas, 1989). Nitrogen yang dapat difiksasi sekitar 2-15 mg N/g. Efek Azotobacter dalam meningkatkan biomassa akar disebabkan oleh penghasilan hormon Indole Acetic Acid (IAA) di daerah perakaran (Rao, 1982).

Azospirillum merupakan salah satu genus Plant Growth Promoting Rhizobacteria (PGPR). Bakteri ini mampu mensintesis hormon pemacu pertumbuhan tanaman seperti IAA, giberelin, dan sitokinin, memfiksasi nitrogen, melarutkan fosfat, mensintesis siderofor, dan sebagai agen pengendali hayati (Salisbury and Ross, 1995; Seshadri et al., 2002; Bashan and Bashan, 2002). Azospirillum adalah bakteri yang bersifat Gram negatif. Suhu optimum untuk pertumbuhannya berkisar antara $32-36{ }^{\circ} \mathrm{C}$, sedangkan $\mathrm{pH}$ optimum berkisar antara 6.8-7.9 (Day and Dubereiner, 1976).

Mikroba Pelarut Fosfat (MPF) merupakan mikroba tanah yang mempunyai kemampuan melarutkan $\mathrm{P}$ tidak tersedia menjadi tersedia. MPF tersebut berasal dari golongan bakteri antara lain: Pseudomonas, Bacillus, Escherichia, Brevibacterium dan Serratia dan dari golongan fungi seperti Aspergillus, Penicillium, Sclerotium dan Fusarium (Alexander, 1978; Rao, 1982). Sebagian dari bakteri genus Pseudomonas dan Bacillus dan sebagian dari fungi genus Pennicillium dan Aspergillus memiliki kemampuan untuk melarutkan $\mathrm{P}$ tidak larut dalam tanah menjadi larut dengan mengeluarkan asam-asam organik (Rao, 1994) seperti: asam sitrat, glutamat, suksinat, laktat, 
asam formiat, asetat, propionat, glikolat, okasalat, malat, fumarat, tartrat dan $\alpha$-ketobutirat yang mampu mengkhelat kation-kation logam $\mathrm{Al}^{3+}, \mathrm{Fe}^{3+}, \mathrm{Ca}^{2+}, \mathrm{Mg}^{2+}$ (Alexander, 1978; Rao, 1982). Asam-asam organik tersebut bersifat non-volatil, sehingga kation yang dikhelat menjadi bentuk stabil (Rao, 1982) dan ion $\mathrm{H}_{2} \mathrm{PO}_{4}{ }^{-}$menjadi bebas dari ikatannya dan tersedia bagi tanaman untuk diserap.

Tujuan penelitian ini adalah untuk menguji efektivitas pupuk organik hayati Biost, Fertismart, Ponti, dan pupuk organik Double Organic Phosphate (DOP) dalam menggantikan sebagian pupuk anorganik (Urea, SP-36, dan $\mathrm{KCl})$ terhadap pertumbuhan tanaman sweet sorghum [Sorghum bicolor (L.) Moench].

\section{BAHAN DAN METODE}

Penelitian diawali pada bulan Maret sampai bulan Juni 2008. Media tanam yang digunakan dalam penelitian ini adalah tanah Latosol Cimahpar. Tanah Latosol dari daerah tersebut miskin akan unsur hara. Bahan yang digunakan adalah benih sweet sorghum varietas Super Sugar yang diperoleh Ibaraki University, Jepang. Sebagai sumber N, P, dan $\mathrm{K}$ dalam penelitian ini berturut-turut adalah pupuk Urea $(40.24 \% \mathrm{~N})$, SP-36 $\left(27.35 \% \mathrm{P}_{2} \mathrm{O}_{5}\right)$, dan $\mathrm{KCl}\left(60 \% \mathrm{~K}_{2} \mathrm{O}\right)$, pupuk organik hayati yaitu: Fertismart, Biost, Ponti, dan pupuk organik Double Organik Phosphate (DOP).

Penelitian di rumah kaca menggunakan Rancangan Acak Lengkap dengan 6 perlakuan pupuk. Masing-masing perlakuan diulang sebanyak 4 kali sehingga diperoleh 24 satuan percobaan. Analisis data dengan metode Duncan Multiple Range Test (DMRT) pada taraf 5\%. Sedangkan penelitian lapang menggunakan Rancangan Acak Lengkap dengan 7 perlakuan pupuk yang diulang sebanyak 4 kali sehingga diperoleh 28 satuan percobaan. Analisis data penelitian lapang dengan metode DMRT dan Least Significant Difference (LSD) pada taraf 5\%.

Contoh tanah pada penelitian rumah kaca dimasukkan dalam pot dengan berat tanah masing-masing $5 \mathrm{~kg}$ tanah/pot (BKM). Pupuk anorganik dicampur dengan setengah bagian tanah dalam pot, sedangkan pupuk organik hayati dan pupuk organik dicampurkan dengan tanah tempat benih akan ditanam. Ketiga jenis pupuk tersebut diberikan satu kali sebelum tanam sesuai dengan takaran yang disajikan pada Tabel 1. Kemudian tanah diinkubasi selama satu minggu.

Tabel 1. Takaran Pupuk Anorganik, Pupuk Organik Hayati, dan Pupuk Organik pada Penelitian Rumah Kaca

\begin{tabular}{|c|c|c|c|c|c|}
\hline \multirow[b]{2}{*}{ Perlakuan } & \multicolumn{5}{|c|}{$\mathrm{Kg} \mathrm{ha}^{-1}\left(\mathrm{~g} \mathrm{pot}^{-1}\right)$} \\
\hline & Urea & SP-36 & $\mathrm{KCl}$ & $\begin{array}{c}\text { Pupuk } \\
\text { Organik } \\
\text { Hayati }\end{array}$ & $\begin{array}{c}\text { Pupuk } \\
\text { Organik }\end{array}$ \\
\hline Kontrol & 0 & 0 & 0 & 0 & 0 \\
\hline $100 \%$ NPK & $300(4.2)$ & $100(1.6)$ & $250(3.0)$ & 0 & 0 \\
\hline $50 \% \mathrm{~N}+\mathrm{DOP}$ & $150(2.1)$ & 0 & 0 & 0 & $250(3.0)$ \\
\hline $50 \%$ NPK + Fertismart & $150(2.1)$ & $50(0.8)$ & $125(1.5)$ & $250(3.0)$ & 0 \\
\hline $50 \%$ NPK + Ponti & $150(2.1)$ & $50(0.8)$ & $125(1.5)$ & $250(3.0)$ & 0 \\
\hline $50 \% \mathrm{NPK}+$ Biost & $150(2.1)$ & $50(0.8)$ & $125(1.5)$ & $250(3.0)$ & 0 \\
\hline
\end{tabular}

Parameter yang diamati adalah: 1) Tinggi sweet sorghum (diukur setiap minggu mulai umur 2 - 6 MST), 2) Jumlah daun, 3) Bobot Basah Tanaman Bagian Atas (BBTBA), 4) Bobot Basah Akar (BBA), 5) Bobot Kering Tanaman Bagian Atas (BKTBA), dan 6) Bobot Kering Akar (BKA).

Pada umur 6 MST dilakukan pemanenan untuk mengetahui BBTBA, BBA, BKTBA, dan BKA. BBTBA dan BBA diukur dengan menimbang bagian atas tanaman dan akar secara terpisah. Setelah penimbangan bobot basah tanaman, bagian atas tanaman dan akar dikeringkan dalam oven pada suhu $60^{\circ}$ selama $2 \times 24$ jam. Setelah itu, bagian atas dan akar tanaman ditimbang kembali untuk mendapatkan nilai BKTBA dan BKA.

Pada penelitian di lapang, tanah dibersihkan dari gulma kemudian diolah dengan lapisan olah sedalam 20 $\mathrm{cm}$. Pada penelitian ini, penanaman sweet sorghum dilakukan pada petak-petak berukuran $2 \times 2.5 \mathrm{~m}$. Jarak antarpetak percobaan berupa parit yang dibuat dengan lebar $50 \mathrm{~cm}$. Pupuk anorganik diberikan di alur sedalam $1 \mathrm{~cm}$, sedangkan pupuk organik hayati dan pupuk organik diberikan di samping benih dengan takaran $3.0 \mathrm{~g} / \mathrm{lubang}$ tanam. Pemupukan dilakukan satu kali pada saat tanam sesuai dengan takaran yang disajikan pada Tabel 2 .

Tabel 2. Takaran Pupuk Anorganik, Pupuk Organik Hayati, dan Pupuk Organik pada Penelitan Lapang

\begin{tabular}{|c|c|c|c|c|c|}
\hline \multirow[b]{2}{*}{ Perlakuan } & \multicolumn{3}{|c|}{$\mathrm{Kg} \mathrm{ha}^{-1}\left(\right.$ g petak $\left.^{-1}\right)$} & \multicolumn{2}{|c|}{$\mathrm{Kg} \mathrm{ha}^{-1}$ (g tiap lubang tanam ${ }^{-1}$ ) } \\
\hline & Urea & SP-36 & $\mathrm{KCl}$ & $\begin{array}{c}\text { Pupuk } \\
\text { Organik } \\
\text { Hayati }\end{array}$ & Pupuk Organik \\
\hline Kontrol & 0 & 0 & 0 & 0 & 0 \\
\hline $100 \% \mathrm{NPK}$ & $300(150)$ & $100(66)$ & $250(125)$ & 0 & 0 \\
\hline $50 \% \mathrm{~N}+\mathrm{DOP}$ & $150(150)$ & 0 & 0 & 0 & $250(3.0)$ \\
\hline $50 \% \mathrm{NPK}+$ Fertismart & $150(150)$ & $50(66)$ & $125(125)$ & $250(3.0)$ & 0 \\
\hline $50 \% \mathrm{NPK}+$ Ponti & $150(150)$ & $50(66)$ & $125(125)$ & $250(3.0)$ & 0 \\
\hline $50 \%$ NPK + Biost & $150(150)$ & $50(66)$ & $125(125)$ & $250(3.0)$ & 0 \\
\hline
\end{tabular}


Setiap petak percobaan diambil 6 tanaman contoh dan 1 tanaman bukan contoh yang ditetapkan secara acak. Masing-masing tanaman contoh dipanen pada 14 MST untuk pengamatan parameter tinggi tanaman, jumlah daun, dan bobot basah batang sweet sorghum. Tanaman bukan contoh dipanen pada 16 MST untuk mengetahui kandungan gula pada batang.

\section{HASIL DAN PEMBAHASAN}

\section{A. Penelitian Rumah Kaca}

\section{Pengaruh Pupuk Organik Hayati terhadap Tinggi Sweet Sorghum}

Tabel 3 menunjukkan bahwa perlakuan 100\%NPK= $50 \%$ NPK + (Fertismart, Ponti, Biost). Hal ini berarti pupuk organik hayati nyata meningkatkan tinggi tanaman dibandingkan dengan kontrol dan mampu menyamai perlakuan $100 \%$ NPK pada 3 MST, 4 MST, dan 5 MST. Perlakuan 50\%NPK + Biost pada 3 MST nyata meningkatkan tinggi tanaman dibandingkan dengan kontrol sebesar $47.8 \%$, diikuti oleh perlakuan 50\% NPK + Fertismart dengan besar peningkatan terhadap kontrol sebesar 40\%. Pada 4 MST, besar peningkatan tinggi tanaman oleh perlakuan $50 \% \mathrm{NPK}+$ Fertismart, $50 \% \mathrm{NPK}+$ Ponti dan 50\%NPK + Biost berturut-turut terhadap kontrol yaitu 43,5\%, 43.2\%, dan 50\%. Sedangkan pada 5 MST, perlakuan $50 \%$ NPK + Fertismart, $50 \%$ NPK + Ponti dan $50 \% \mathrm{NPK}+$ Biost berturut-turut mampu meningkatkan tinggi tanaman sebesar $20 \%$, $19.3 \%$, dan $17.7 \%$ terhadap kontrol.

Tabel 3. Pengaruh Pemupukan terhadap Tinggi Sweet Sorghum

\begin{tabular}{|c|c|c|c|c|}
\hline \multirow{2}{*}{ Perlakuan } & $2 \mathrm{MST}$ & $3 \mathrm{MST}$ & 4MST & 5MST \\
\hline & \multicolumn{4}{|c|}{ 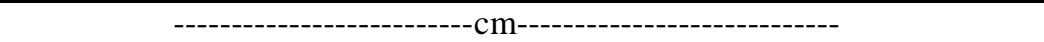 } \\
\hline Kontrol & $25.71 \mathrm{a}$ & $34.93 a$ & $44.63 \mathrm{a}$ & $68.88 \mathrm{a}$ \\
\hline $100 \%$ NPK & $30.13 \mathrm{a}$ & $47.90 \mathrm{bc}$ & $65.63 b$ & 83.00b \\
\hline $50 \% \mathrm{~N}+\mathrm{DOP}$ & $30.46 a$ & $39.30 \mathrm{ab}$ & $47.81 \mathrm{a}$ & $73.06 \mathrm{ab}$ \\
\hline $50 \%$ NPK + Fertismart & $31.30 \mathrm{a}$ & $48.96 \mathrm{bc}$ & $64.00 \mathrm{~b}$ & $82.63 b$ \\
\hline $50 \%$ NPK + Ponti & $27.90 \mathrm{a}$ & $46.99 \mathrm{bc}$ & $63.94 b$ & $82.13 b$ \\
\hline $50 \%$ NPK + Biost & 31.63a & $51.64 c$ & $66.94 b$ & $81.06 \mathrm{~b}$ \\
\hline
\end{tabular}

Hal ini berarti bahwa $250 \mathrm{~kg} / \mathrm{ha}$ Fertismart, Biost, dan Ponti mampu menggantikan $150 \mathrm{~kg} / \mathrm{ha}$ urea, $50 \mathrm{~kg} / \mathrm{ha} \mathrm{SP}$ 36 , dan $125 \mathrm{~kg} / \mathrm{ha} \mathrm{KCl}$.

Penyebab pertumbuhan tanaman adalah karena selain pupuk organik hayati mengandung unsur hara, juga karena mikroba yang terkandung di dalamnya mampu meningkatkan efisiensi pengambilan unsur hara oleh tanaman yang tercermin dari peningkatan pertumbuhan. Mikroba tersebut juga mampu menghasilkan hormon pertumbuhan Indole Acetic Acid (IAA) yang dapat menunjang pertumbuhan tanaman. Bakteri Azotobacter selain dapat mensubsitusi hara khususnya nitrogen juga menghasilkan hormon tumbuh dan senyawa fungisida yang dapat mencegah pertumbuhan cendawan yang dapat menekan pertumbuhan dan produksi tanaman (Syam'un dan Dachlan, 2006).

Perlakuan dengan pupuk organik Double Organic Phosphate (DOP) tidak nyata meningkatkan tinggi tanaman dibandingkan dengan blanko. Hal ini disebabkan karena pupuk DOP tidak mengandung mikroba fungsional yang dapat melarutkan fosfat sukar larut sehingga menjadi tersedia bagi tanaman. Ketersediaan fosfat tergantung dari kelarutannya, banyak pelarut, jarak dari ion fosfat untuk mencapai akar, dan mikroba untuk dapat menyerapnya (Partohardjono, 1991).

\section{Pengaruh Pupuk Organik Hayati terhadap Jumlah Daun Sweet Sorghum}

Peningkatan jumlah daun terbesar ditunjukkan oleh perlakuan $50 \%$ NPK + Biost sebesar $29 \%$ terhadap kontrol pada 3 MST dan $34.8 \%$ pada 4 MST (Tabel 4). Ketersediaan unsur hara nitrogen melalui pemupukan urea dan penambatan oleh bakteri non simbiotik serta serapannya oleh tanaman menjadi penyebab meningkatnya jumlah daun.

Tabel 4. Pengaruh Pemupukan terhadap Jumlah Daun Sweet Sorghum

\begin{tabular}{|c|c|c|c|c|}
\hline \multirow{2}{*}{ Perlakuan } & $2 \mathrm{MST}$ & 3MST & 4MST & 5MST \\
\hline & \multicolumn{4}{|c|}{------------------------lembar pot ${ }^{-1}$--------------------- } \\
\hline Kontrol & $4.13 a$ & $4.75 \mathrm{a}$ & $5.75 \mathrm{a}$ & $7.25 \mathrm{a}$ \\
\hline $100 \%$ NPK & $4.63 b$ & $5.75 b$ & $7.13 \mathrm{c}$ & 7.38a \\
\hline $50 \% \mathrm{~N}+\mathrm{DOP}$ & $4.00 \mathrm{a}$ & $5.00 \mathrm{a}$ & $6.00 \mathrm{ab}$ & $7.13 \mathrm{a}$ \\
\hline $50 \%$ NPK + Fertismart & $4.63 b$ & $5.63 b$ & $7.00 \mathrm{bc}$ & $7.13 \mathrm{a}$ \\
\hline $50 \%$ NPK + Ponti & $4.38 \mathrm{ab}$ & $5.75 b$ & $7.38 \mathrm{c}$ & $7.00 \mathrm{a}$ \\
\hline $50 \%$ NPK + Biost & $4.75 b$ & 6.13b & $7.75 c$ & $7.25 \mathrm{a}$ \\
\hline
\end{tabular}

Secara umum, hasil penelitian menunjukkan bahwa perlakuan pemupukan kombinasi antara pupuk anorganik dengan pupuk organik hayati Fertismart, Biost, dan Ponti secara signifikan dapat memberikan peningkatan tinggi tanaman dan jumlah daun yang lebih baik dibandingkan dengan kontrol. Akan tetapi, tidak signifikan dibandingkan dengan perlakuan $100 \%$ NPK. Hal ini menunjukkan bahwa ketiga pupuk organik hayati tersebut mampu mensubstitusi $50 \%$ kebutuhan pupuk anorganik pada sweet sorghum. 
3. Pengaruh Pupuk Organik Hayati terhadap Bobot Basah Tanaman Bagian Atas (BBTBA), Bobot Basah Akar (BBA), Bobot Kering Tanaman Bagian Atas (BKTBA) dan Bobot Kering Akar (BKA) Sweet Sorghum

Pengaruh pemupukan dengan kombinasi pupuk anorganik dan pupuk organik hayati nyata meningkatkan BKTBA dan BKA sweet sorghum. Pada Tabel 5 dapat diketahui bahwa pemupukan tanaman dengan kombinasi pupuk anorganik dan pupuk organik hayati dapat meningkatkan BKTBA dan BKA dibandingkan dengan kontrol, tetapi tidak berbeda nyata dengan $100 \%$ NPK. Hal ini menunjukkan bahwa penggunaan pupuk organik hayati mampu menggantikan kebutuhan terhadap pupuk NPK sebesar $50 \%$ atau $150 \mathrm{~kg} / \mathrm{ha}$ urea, $50 \mathrm{~kg} / \mathrm{ha}$ SP-36, dan 125 $\mathrm{kg} / \mathrm{ha} \mathrm{KCl}$ pada sweet sorghum.

Tabel 5. Pengaruh Pemupukan terhadap Bobot Basah Tanaman Bagian Atas (BBTBA), Bobot Basah Akar (BBA), Bobot Kering Tanaman Bagian Atas (BKTBA) dan Bobot Kering Akar (BKA) Sweet Sorghum

\begin{tabular}{|c|c|c|c|c|}
\hline \multirow{3}{*}{ Perlakuan } & \multicolumn{2}{|c|}{ Bobot Tanaman Atas } & \multicolumn{2}{|c|}{ Bobot Akar } \\
\hline & Basah & Kering & Basah & Kering \\
\hline & \multicolumn{4}{|c|}{ 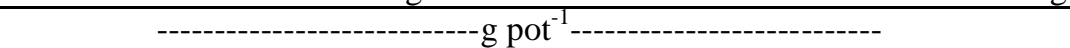 } \\
\hline Blanko & $14.72 \mathrm{a}$ & $1.91 \mathrm{a}$ & $1.91 \mathrm{a}$ & $0.61 \mathrm{a}$ \\
\hline $100 \%$ NPK & 20.11a & $2.96 \mathrm{c}$ & $2.76 \mathrm{ab}$ & $0.91 \mathrm{c}$ \\
\hline $50 \% \mathrm{~N}+\mathrm{DOP}$ & $15.09 \mathrm{a}$ & $2.08 \mathrm{ab}$ & $1.79 \mathrm{a}$ & $0.58 \mathrm{a}$ \\
\hline $50 \%$ NPK + Fertismart & $18.77 \mathrm{a}$ & $2.73 \mathrm{c}$ & $2.31 \mathrm{ab}$ & $0.77 \mathrm{abc}$ \\
\hline $50 \%$ NPK + Ponti & $20.10 \mathrm{a}$ & $2.89 \mathrm{c}$ & $2.97 b$ & $0.97 c$ \\
\hline $50 \%$ NPK + Biost & $17.64 \mathrm{a}$ & $2.56 \mathrm{c}$ & $2.63 \mathrm{ab}$ & $0.85 b c$ \\
\hline
\end{tabular}

Perlakuan 50\%NPK + Ponti diikuti perlakuan $50 \%$ NPK + Fertismart dan perlakuan $50 \%$ NPK + Biost nyata meningkatkan BKTBA berturut-turut sebesar 50.3\%, $42.9 \%$, dan $35 \%$ dibandingkan dengan kontrol, tetapi tidak berbeda nyata dengan perlakuan $100 \%$ NPK. Sedangkan perlakuan $50 \% \mathrm{NPK}+$ Ponti nyata meningkatkan BKA sebesar 59\% terhadap kontrol, tetapi tidak berbeda nyata dengan $100 \%$ NPK.

Pengaruh pemupukan baik dengan $100 \%$ NPK maupun dengan $50 \% \mathrm{~N}+$ DOP dan $50 \% \mathrm{NPK}+($ Fertismart, Ponti, Biost) tidak menunjukkan perbedaan yang nyata terhadap peningkatan BBTBA jika dibandingkan dengan kontrol. Perlakuan $50 \%$ NPK + Ponti, 50\%NPK + Biost dan $50 \% \mathrm{NPK}+$ Fertismart nyata meningkatkan BBA dibandingkan dengan kontrol berturut-turut sebesar 52.6\%, $36.8 \%$ dan $21 \%$ tetapi tidak berbeda nyata dengan $100 \%$ NPK. Pemberian bakteri pelarut fosfat menyebabkan meningkatnya $\mathrm{P}$ tersedia tanah sehingga pertumbuhan akar menjadi lebih baik (Aidi, 2003). Perlakuan 50\%NPK + Ponti diikuti perlakuan $50 \%$ NPK + Biost, dan perlakuan $50 \%$ NPK + Fertismart nyata meningkatkan BKA tanaman masing-masing sebesar 49\%, 39.3\%, dan 26\% dibandingkan dengan kontrol, tetapi tidak berbeda nyata dengan $100 \%$ NPK.

\section{B. Hasil dan Pembahasan Penelitian Lapang}

Pengaruh Pupuk Organik Hayati terhadap Tinggi, Jumlah Daun, Bobot Basah Batang, Kandungan Gula Batang dan Bobot Basah Tanaman Bagian Atas (BBTBA) Sweet Sorghum

Pada Tabel 6 terlihat bahwa perlakuan 50\%NPK + Fertismart nyata meningkatkan tinggi tanaman, jumlah daun dan BBTBA dibandingkan dengan kontrol berturutturut sebesar $72.8 \%$, 39.5\% dan $90.6 \%$ dan setara dengan $100 \%$ NPK. Perlakuan $50 \%$ NPK + Ponti nyata meningkatkan tinggi tanaman dan jumlah daun dibandingkan dengan kontrol masing-masing sebesar $56.8 \%$ dan $30 \%$, tetapi tidak berbeda nyata dengan $100 \%$ NPK.

Tabel 6. Pengaruh pemupukan terhadap Tinggi Tanaman, Jumlah Daun, Bobot Basah Batang, Kandungan Gula Batang dan BBTBA

\begin{tabular}{|c|c|c|c|c|c|c|c|c|c|}
\hline \multirow{3}{*}{ Perlakuan } & \multirow{3}{*}{$\begin{array}{c}\text { Tinggi } \\
\text { Tanaman } \\
----c m----\end{array}$} & \multirow{3}{*}{$\begin{array}{l}\text { Jumlah } \\
\text { daun } \\
\text { lembar }\end{array}$} & \multicolumn{3}{|c|}{ Bobot Basah Batang } & \multicolumn{3}{|c|}{ Kandungan Gula Batang } & \multirow{3}{*}{$\begin{array}{l}\text { BВТВА } \\
\mathrm{kg} \text { petak }\end{array}$} \\
\hline & & & Atas & Tengah & Bawah & Atas & Tengah & Bawah & \\
\hline & & & \multicolumn{3}{|c|}{-----------kg petak ${ }^{-1}$--------- } & \multicolumn{3}{|c|}{------------------\%o---------------- } & \\
\hline Blanko & $78.06 a$ & $7.17 \mathrm{a}$ & $0.33 \mathrm{a}$ & $0.58 \mathrm{a}$ & $0.68 \mathrm{a}$ & $7.68 \mathrm{ab}$ & $13.60 \mathrm{a}$ & $12.05 \mathrm{ab}$ & $2.35 \mathrm{a}$ \\
\hline $50 \% \mathrm{NPK}$ & $104.13 \mathrm{abc}$ & $8.38 \mathrm{ab}$ & $0.45 \mathrm{a}$ & $0.78 \mathrm{ab}$ & $0.86 a$ & $9.50 \mathrm{ab}$ & $13.28 \mathrm{a}$ & $13.65 b$ & $2.70 \mathrm{a}$ \\
\hline $100 \%$ NPK & $124.44 b c$ & $9.99 b$ & $0.60 a$ & $1.08 \mathrm{~b}$ & $1.43 b$ & $7.45 \mathrm{ab}$ & $14.00 \mathrm{a}$ & $13.38 b$ & $4.63 b$ \\
\hline $\begin{array}{l}50 \% \mathrm{~N} \\
+ \text { DOP }\end{array}$ & $104.69 \mathrm{abc}$ & $8.29 \mathrm{ab}$ & $0.48 \mathrm{a}$ & $0.88 \mathrm{ab}$ & $1.08 \mathrm{ab}$ & 10.13b & $11.65 \mathrm{a}$ & $9.20 \mathrm{a}$ & $3.68 \mathrm{ab}$ \\
\hline $\begin{array}{c}50 \% \text { NPK } \\
\text { +Fertismart }\end{array}$ & $134.88 c$ & $10.00 b$ & $0.53 a$ & $0.98 \mathrm{ab}$ & $1.13 \mathrm{ab}$ & $7.15 \mathrm{a}$ & $12.63 \mathrm{a}$ & $9.50 \mathrm{a}$ & $4.48 b$ \\
\hline $\begin{array}{c}50 \% \text { NPK }+ \\
\text { Ponti }\end{array}$ & $122.36 \mathrm{bc}$ & $9.33 b$ & $0.44 \mathrm{a}$ & $0.83 a b$ & $1.13 \mathrm{ab}$ & $8.58 \mathrm{ab}$ & $13.63 \mathrm{a}$ & $12.15 \mathrm{ab}$ & $3.73 \mathrm{ab}$ \\
\hline $\begin{array}{c}50 \% \text { NPK }+ \\
\text { Biost }\end{array}$ & $92.73 \mathrm{ab}$ & $8.13 \mathrm{ab}$ & $0.50 \mathrm{a}$ & $0.78 \mathrm{ab}$ & $1.05 \mathrm{ab}$ & $9.23 \mathrm{ab}$ & $14.00 \mathrm{a}$ & $13.65 b$ & $3.48 \mathrm{ab}$ \\
\hline
\end{tabular}


Pemupukan dengan perlakuan 50\%NPK + (Fertismart, Biost, dan Ponti) nyata meningkatkan bobot basah batang dibandingkan dengan kontrol, tetapi tidak nyata jika dibandingkan dengan 100\%NPK. Pemupukan dengan 50\% NPK dan $50 \% \mathrm{~N}+$ DOP tidak nyata meningkatkan tinggi tanaman dan jumlah daun karena dosis pemupukan yang lebih sedikit dari yang direkomendasikan dan tidak adanya mikroba dalam pupuk yang mampu mempercepat tersedianya hara bagi tanaman.

Perlakuan pemupukan nyata meningkatkan kandungan gula dalam batang atas dan batang bawah sweet sorghum dibandingkan dengan kontrol. Pada batang bagian atas, kandungan gula tertinggi ditunjukkan oleh perlakuan $50 \% \mathrm{~N}$ + DOP. Sedangkan pada batang bagian tengah dan bawah, kandungan gula tertinggi ditunjukkan oleh perlakuan $50 \%$ NPK + Biost.

\section{KESIMPULAN}

1. Penelitian di rumah kaca menunjukkan bahwa pupuk organik hayati Fertismart, Ponti, dan Biost nyata meningkatkan tinggi, jumlah daun, Bobot Basah Tanaman Bagian Atas (BBTBA), Bobot Kering Tanaman Bagian Atas (BKTBA), Bobot Basah Akar (BBA), dan Bobot Kering Akar (BKA) sweet sorghum.

2. Penelitian di lapang menunjukkan bahwa pupuk organik hayati Fertismart, Ponti, dan Biost nyata meningkatkan tinggi, jumlah daun, BBTBA, dan kandungan gula batang sweet sorghum.

3. Pupuk organik hayati Fertismart, Ponti, dan Biost mampu mensubstitusi 50\% kebutuhan pupuk anorganik pada sweet sorghum.

\section{DAFTAR PUSTAKA}

Aidi, N. 2003. Pengaruh fosfat alam dan kombinasi bakteri pelarut fosfat dengan pupuk kandang terhadap $\mathrm{P}$ tersedia dan pertumbuhan kedelai pada ultisol. Buletin Agronom., 3: 100 - 106.
Alexander, M. 1978. Introduction to Soil Microbiology. $2^{\text {nd }}$ ed. Willey Eastern Private Limited. New Delhi.

Bashan, Y and L.E. Bashan. 2002. Protection of tomato seedlings against infection by Pseudomonas syringae pv. Tomato by using the plant growth-promoting bacterium Azospirillum brasilense. Appl Environ Microbiol, 6: 2673 - 2643.

Day, J.M. and J. Dobereiner. 1976. Physiologycal aspects of $\mathrm{N}_{2}$ fixation by Azosprillum from digitania roots. Soil Biol.Biochem., 8: 45 - 50.

Imas, T. 1989. Mikrobiologi Tanah II. Pusat Antar Universitas Bioteknologi. Institut Pertanian Bogor. Bogor.

Partohardjono, M.S.I. 1991. Fosfor Peranan dan Penggunaannya dalam Bidang Pertanian. Balai Penelitian Tanaman Pangan. Bogor.

Rao, N. S. 1982. Biofertilizers In Agriculture. Oxford \& IBH Publishing Co. Oxford.

1994. Mikroorganisme Tanah dan Pertumbuhan Tanaman, Edisi 2. Universitas Indonesia Press. Jakarta.

Razie, F. 2003. Karakteristik Azotobacter spp. dan Azospirillum spp. dari Rhizosfer Padi Sawah di Daerah Dataran Banjir Kalimantan Selatan dan Pengaruhnya terhadap Pertumbuhan Awal Tanaman Padi. Tesis. Sekolah Pascasarjana. Institut Pertanian Bogor. Bogor.

Salisbury, F.B. and C.W. Ross. 1995. Fisiologi Tumbuhan Dasar. Lukman D.R. Sumaryono (penerjemah). ITB Press. Bandung.

Seshadri, S., R. Muthukumarasamy, C. Lakshminarasimhan, S. Ignacimuthu. 2000. Solubilization of inorganic phosphates by Azospirillum halopraeferans. Curr Sci., 5: 565 - 567.

Syam'un, E. dan A. Dachlan 2006. Pengembangan Agen Mikroba Penambat Nitrogen. Lembaga Penelitan Universitas Hasanuddin. Makassar. 